\title{
Potensi Pemanfaatan Ekosistem Pesisir Pantai Labuhan Haji Lombok Timur Sebagai Daerah Ekowisata
}

\author{
Deni Apriana S. ${ }^{1}$ dan Daindo Milla ${ }^{1}$ \\ ${ }^{1}$ Mahasiswa Program Studi Pendidikan IPA Universitas Mataram \\ E-mail: dhesenja487@gmail.com
}

\begin{abstract}
Abstrak
Penelitian ini bertujuan untuk menganalisis potensi-potensi yang dimiliki oleh ekosistem pesisir pantai Labuhan Haji Lombok Timur untuk dikembangkan menjadi daerah ekowisata. Metode penelitian yang digunakan adalah analisis deskriptif melalui kegiatan kajian pustaka/ literature yang dilakukan untuk mendapatkan informasi terkait dengan judul penelitian. Hasil analisis menunjukkan bahwa ekosistem pesisir pantai Labuhan Haji memiliki potensi yang besar dalam memberikan jasa/ layanan ekosistem khususnya jasa kebudayaan dari ekosistem tersebut. Potensi yang dimiliki diantaranya memiliki bentang alam indah yang banyak dimanfaatkan oleh wisatawan yang ingin melihat keindahan matahari saat terbit, pantai dengan ombak yang tidak terlalu tinggi, dikelilingi oleh persawahan dan perkebunan masyarakat yang masih alami. Banyaknya potensi yang dimiliki oleh ekosistem pesisir Pantai Labuhan Haji yang didukung oleh peran serta masyarakat sebagai pengelola dan wisawatan untuk memelihara dan menjaga ekosistem tersebut dari kerusakan ataupun terhadap pencemaran lingkungan mennyebabkan ekosistem pesisir pantai Labuhan Haji tepat jika dikembangkan sebagai salah satu daerah ekowisata yang ada di Lombok Timur.
\end{abstract}

Kata Kunci: Ekosistem pesisir, Jasa kebudayaan Ekosistem, Ekowisata.

\begin{abstract}
Abstact
This study aims to analyze the potentials possessed by the coastal ecosystem of Labuhan Haji Lombok Timur to be developed into ecotourism area. The research method used is descriptive analysis through literature review activities / literature conducted to obtain information related to the title of research. The results of the analysis indicate that the coastal ecosystem of Labuhan Haji has great potential in providing ecosystem services / services, especially the cultural services of the ecosystem. Potentials of which have beautiful landscapes are widely used by tourists who want to see the beauty of the sun when rising, the beach with a wave that is not too high, surrounded by rice fields and plantations that are still natural communities. The number of potency possessed by coastal ecosystem of Labuhan Haji Beach which supported by society participation as manager and wisawatan to maintain and maintain the ecosystem from damage or to environmental pollution mennyebabkan coastal ecosystem Labuhan Haji precisely if developed as one of ecotourism area in Lombok East.
\end{abstract}

Keywords: coastal ecosystem, ecosystem services, ecotourism. 


\section{Pendahuluan}

Indonesia memiliki sumberdaya alam yang melimpah yang ditinjau dari kuantitas dan keanekaragaman produknya. Sumber daya alam merupakan potensi yang dimiliki oleh suatu Negara sebagai upaya untuk memenuhi kebutuhan ekonomi maupun dibutuhkan dalam kegiatan pembangunan, dalam rangka memenuhi kebutuhan hidup manusia unutk mencapai kehidupan masyarakat yang sejahtera. Sebagai negara pesisir, Indonesia memiliki potensi sumber daya alam hayati dan nonhayati, sumber daya buatan, serta jasa lingkungan yang sangat penting bagi kehidupan masyarakat.

Wilayah pesisir merupakan wilayah yang unik dengan karakter yang spesifik. Artinya bahwa wilayah pesisir merupakan wilayah yang sangat dinamis dengan perubahanperubahan biologis, kimiawi dan geologis yang sangat cepat. Ekosistem Wilayah pesisir terdiri dari terumbu karang, hutan bakau, pantai dan pasir, estuari, lamun yang merupakan pelindung alam dari erosi, banjir dan badai serta dapat berperan dalam mengurangi dampak polusi dari daratan ke laut. Disamping itu wilayah pesisir juga menyediakan berbagai jasa lingkungan dan sebagai tempat tinggal manusia, dan untuk sarana transportasi, tempat berlibur atau rekreasi (Dahuri, et. al. 2001).

Terkait dengan jasa lingkungan yang diberikan oleh ekosistem pesisir sebagai tempat berlibur dan rekreasi, ekosistem pesisir sangat berpotensi dijadikan sebagai daerah wisata. Pemanfaatan ekosistem sebagai daerah wisata yang akan memberikan manfaat secara spiritual terlebih secara ekonommi bagi masyarakat yang tinggal di sekitar ekosistem pesisir tersebut atapun masyarakat yang ingin mendapatkan jasa yang diberikan langsung oleh ekosistem tersebut.

Berlawanan dengan hal tersebut, banyak aktivitas masyarakat pesisir yang cenderung memanfaatkan ekosistem pesisir secara berlebihan yang menyebabkan rusaknya ekosistem. Seperti penebangan tanaman pada hutan mangrove yang dijadikan sebagai perluasan daerah pemukiman, untuk kayu bakar ataupun untuk reklamasi pantai, penambangan pasir di sekitar ekosistem mangrove dan sebagainya, sangat berpotensi menyebabkan kerusakan pada ekosistem laut dan pesisir yang ada di sekitarnya. Kerusakan yang ditimbulkan pada ekosistem pesisir tersebut akan mengurangi jasa yang diberikan oleh ekosistem tersebut bagi manusia bahkan cenderung akan membahayakan bagi manusia itu sendiri, khususnya nilai keindahan yang diberikan oleh ekosistem pesisir (Sarawaswati, 2004)

Ekowisata adalah salah satu bentuk pemanfaatan jasa budaya yang diberikan oleh ekosistem khususnya ekosistem pesisir sebagai daerah wisata dengan mengeksplorasi keindahan yang diberikan oleh ekosistem pesisir untuk mendatangkan keuntungan ekonomi bagi pengelola ekowisata ataupun masyarakat pesisir yang memanfaatkan daerah pesisir sebagai mata pencaharian, yang diikuti dengan upaya perlindungan, perwatan maupun pemulihan ekosistem pesisir yang dilakukan oleh pengelola ataupun mansyarakat penerima manfaat langsung dari ekosistem pesisir.

Berhubungan dengan uraian di atas, artikel ini berisi hasil kajian pustaka yang menganalisis potensi-potensi yang dimiliki oleh daerah pesisir Pantai Labuhan Haji Lombok Timur untuk dikembangkan menjadi daerah ekowisata.

\section{Potensi Daerah Ekosistem Pesisir Labuhan Haji Kabupaten Lombok Timur Sebagai Daerah Ekowisata}

\subsection{Jasa Kebudayaan Ekosistem}

Kajian ekosistem millennium (the Millennium Ecosystem Assessment/ MEA) membagi jasa ekosistem menjadi 4 kategori, yakni: 1) Penyediaan bahan: produksi pangan, 
air, kayu dan hasil lainnya; 2) Pengontrolan: iklim, banjir, penyakit; 3) Sosial/budaya: peluang untuk keperluan rekreasi, estetik dan spiritual dan 4) Dukungan: memelihara prosesproses yang menjadi landasan bagi layanan jasa lainnya, seperti formasi tanah, polinasi dan siklus nutrient (www.ccres.net).

Jasa budaya/ kultural didefinisikan berdasarkan asalnya sebagai nilai non-materi atau keuntungan yang dihubungkan dnegan ekosistem (Satz et al, 2013). MEA mendekripsikan jasa budaya sebagai bagian dari jasa ekosistem yang merupakan keuntungan masyarakat non-materi yang diproleh dari ekosistem melalui peningkatan spritual, pengembangan kognitif, repleksi, rekreasi, dan pengalaman keindahan, dengan demikian memproleh harga dari nilai-nilai budaya dan pemandangan alam (Pandey et al, 2013).

Arkhan (2015) memberikan contoh pada ekosistem lamun. Ekosistem lamun memiliki jasa ekosistem yang beragam, salah satunya adalah jasa budaya. Jasa budaya ekosistem lamun berupa nilai estetika yang diberikan sehingga dapat digunakan sebagai tempat wisata dan penelitian.

Selain itu, Wahyudin, et al (2016) juga mengatakan bahwa habitat Lamun mempunyai jasa ekosistem yang cukup beragam, khususnya terkait dengan jasa pendukung (supporting survices) dan khususnya sebagai penyedia daerah asuhan (nursey ground), tempat mencari makan (feeding groind), sirkulasi nutrien, dan lainlain. Bahkan lamun mempunyai keterkaitan yang kuat dan berasosiasi dengan beberapa organisme khas dan unik disekitarnya seperti dugong, kuda laut dan penyu laut, yuang semuanya mempunyai ketergantungan terhadap ekosistem lamun. Ekosistem lamun adalah salah satu komponen penting sebagai penyususn kesatuan ekosistem pesisir bersama dengan mangrov dan terumbu karang.
Ekosistem lamun tidak terlalu banyak mendapatkan perhatian padahal ekosistem lamun cukup menyediakan barang dan jasa yang penting dan juga mempunyai distribusi yang cukup menyebar di seluruh dunia.

Layanan kultural ekosistem memberikan kontribusi dalam menempatkan perasaan, membantu mengembangkan keseragaman sosial, dan yang penting untuk kesehatan manusia dan menjadi manusia yang lebih baik. Jasa kultural ekosistem berbeda dengan jasa ekosistem lainnya. Seperti yang diadaftasi dari TEEB (The Economics of Ecosystem Services and Biodiversity ), beberapa bentuk jasa kultural ekosistem yang diproleh dari alam; 1) rekreasi, relaksasi dan kesehatan, 2) pariwisata, 3) menghargai keindahan dan inspirasi kebudayaan, dan 4) keagaamaan dan penjiwaan suatu tempat (The urbes Project, 2015).

Pemanfaatan jasa lingkungan secara lestari dapat dilakukan dengan memanfaatkan jasa lingkungan dalma bentuk kegiatan pariwisata alam, antara lain dalam bentuk Taman Nasional, Taman Hutan Raya dan Taman Wisata Alam (Siswantoro, 2012)

De Groot dalam Loana et al (2013) menjelaskan Penelitian jasa budaya ekosistem mengikutsertakan beberapa disiplim ilmu seperti ekologi, ekonomi dan pengetahuan sosial, dan mengunakan jangkauan pendekatana penelitian yang luas. Walaupun berasal dari banyak dispilin ilmu, metodelogi dan pandangan teoritis, ada persetujuan yang luas pada tingkat yang meumuaskan dari pengetahuan beberapa permasalahan yang bermanfaat dari jasa budaya ekosistem yang belum dicapai.

\subsection{Pengembangan Ekowisata Untuk Melestarikan Ekosistem}

Darmawan (2015), sumber daya alam merupakan salah satu modal pembangunan saat ini dan menjadi tumpuan untuk 
meningkatkan pertumbuhan ekonomi Indonesia. Mengingat peran penting yang diemban oleh sumber daya alam dalam mendukung kehidupan manusia, sangatlah perlu dilakukan berbagai upaya untuk memaksimalkan upaya pemanfaatn dari sumber daya alam tersebut, salah satunya adalah dengan memanfaatkannya sebagai daerah wisata.

Dalam Undang-Undang Nomor 9 Tahun 1990 tentang pariwisata, Usaha pariwisata adalah kegaitan yang bertujuan menyelenggrakan jasa pariwiwsata atau menyediakan atau mengusahakan objek dan daya tarik wisata, usaha sarana wisata, dan kegiatan lain yang terkait dengan pariwisata.

Menurut Gunn (1994) perencanaan pengembangan pariwisata ditentukan oleh keseimbangan potensi sumberdaya dan jasa yang dimiliki sebagai penawaran dan permintaan atau minat wisatawan sebagai permintaan. Komponen penawaran terdiri dari: a) atraksi (potensi keindahan alam dan budaya serta bentuk aktivitas wisata); b) transportasi (aksesibilitas); c) pelayanan informasi; dan d) akomodasi dan sebagainya.

Beberapa Strategi Pengembangan suatu ekosistem sebagai bentuk layanan kebudayaan yang diberikan dalam bentuk Ekowisata:

1. Faktor-Faktor Internal (IFAS)

a. Kekuatan (Strengths)

- Potensi alam yang mendukung untuk dilakukan kegiatan ekowisata.

- Sarana dan Prasarana yang cukup memadai.

- Keberadaan kelompok masyarakat sebagai pengelola sumberdaya mangrove.

b. Kelemahan (Weakness)

- Rendahnya pemahaman masyarakat dan pengunjung tentang sumberdaya dan ekosistem mangrove dan juga ekowisata.
- Kurangnya dukungan dari pemerintah desa setempat .

- Kurangnya informasi/promosi tentang adanya wisata mangrove di desa Sei Nagalawan.

2. Faktor-Faktor Eksternal (EFAS)

a. Peluang (Opportunities)

- Tingginya minat wisatawan untuk melakukan kegiatan wisata mangrove.

- Lokasi tempat wisata yang strategis.

- Menghasilkan produk unggulan hasil dari sumberdaya mangrove dan satu - satunya di Sumatera Utara.

b. Ancaman (Threats)

- Persaingan dengan obyek wisata yang lain.

- Dampak negatif dari aktifitas wisata (sampah, potensi buangan limbah, kegiatan yang merusak ekosistem mangrove, dll).

- Konflik kepentingan (Muttaqin, 2011).

\subsection{Keadaan Ekosistem Pantai Labuhan haji Kabupaten Lombok Timur}

Lombok timur merupkaan satu dari Sembilan kabupaten/ kota yang ada di Nusa Tenggara Barat yang menjadi tujuan wisata karena salah satu yang disebabkan oleh keadaan pantainya. Dinas Pariwisata Kabupaten Lombok Timur mencatat ada 11 (sebelas) panta yang ada di Lombok Timur yang dijadikan sebagai tujuan wisata. Objek wisata pantai Lombok timur memiliki bentang alam yang indah, air laut yang jernih dan biota bawah laut yang sangat indah untuk dilihat, salah satunya yang dimiliki oleh pantai Labuhan haji (Subhani, 2010).

Dikenal dengan nama labuhan haji, sebuah daerah yang terletak di bagian timur kabupaten Lombok timur. Labuhan haji 
memiliki keindahan pantai yang tak diragukan lagi, yang pada awalnya dijadikan sebagai daerah/ pelabuhan tempat keberangkantan haji pada masa penjajahan belanda dan jepang dan menjadi jalur pintu masuk perdagangan khususnya Cina pada masa itu. Sebagai daerah yang memiliki pantai. Labuhan haji memiliki bentang alam yang indah, dapat menampilkan keindahan keemasan sinar mentari pagi, memiliki taman dan pepohonan yang rindang, memiliki pemandangan persawahan yang masing alami, dan dapat memandang pemandangan laut yang biru secara leluasa (Turmuzi, 2015).

Pemerintah selaku pengelola mengembangkan pantai labuhan haji sebagai salah satu daerah wisata yang ada di Lombok timur melihat potensi keindahan yang dimiliki. Tapi yang sangat disayangkan, kondisi tersebut tidak dibarengi dengan upaya pemeliharaan yang harusnya dilakukan oleh pelaku wisata ataupun penerima manfaat langsung ekosistem tersebut. Hal tersebut terlihat dari penataan lokasi pedangan yang semrawut, sampah platik yang banyak mencemari pantai yang dibuang sembarangan oleh wisatawan ataupun oleh pedangan yang tidak memperhatikan kebersihan lingkungan. Padahal jika itu dikelola dengan baik, dilakukan penataan sebaik mungkin, dan sosialisasi kebersihan yang dilakukan oleh pemerintah dan pengelola dan dari kesadaran masyarakat sendiri, jelas akan mendatangkan keuntungan yang berlipat ganda, dari segi jumlah wisatawan yang berkunjung, segi ekonomi maupun mata pencaharian penduduk local.

\subsection{Ekowisata sebagai Bentuk Pemanfaatan Jasa Kultural Ekosistem \\ Dalam Peraturan Menteri Lingkungan Hidup (Permen LH) No.17 Tahun 2009 tentang Pedoman Penentuan Daya Dukung Lingkungan Hidup, dalam Penataan Ruang}

Wilayah, penentuan daya dukung lingkungan dilakukan dengan pendekatan berbasis potensi seperti kapasitas bioekologi. Namun itu bukanlah satusatunya pendekatan. Di banyak negara maju, sudah digunakan pula metode/ pendekatan yang berbasis jasa ekosistem seperti yang dikembangkan Millenium Ecosystem Assesment (MEA) pada tahun 2005. Dalam pendekatan ini dilihat berdasarkan konteks "manfaat yang diperoleh masyarakat dari ekosistem". Contohnya antara lain meliputi produksi pangan dan obatobatan, pengaturan iklim dan penyakit, tersedianya tanah produktif dan air bersih, perlindungan terhadap bencana alam, peluang untuk rekreasi, terpeliharanya warisan budaya dan manfaat spiritual

Konsep Pengembangan Ekowisata antara lain: Pertama, aspek destinasi, kemudian kedua adalah aspek market. Untuk pengembangan ekowisata dilaksanakan dengan konsep product driven. Meskipun aspek market perlu dipertimbangkan namun macam, sifat dan perilaku obyek dan daya tarik wisata alam dan budaya diusahakan untuk menjaga kelestarian dan keberadaannya (Pengusahaan Ekowisata (2000)).

Partisivasi masyarakat dalam perencanaan. Masyarakat diajak dalam merencanakan pengembangan ekowisata. Demikian pula di dalam pengawasan, peran masyarakat diharapkan ikut secara aktif. Penghasilan masyarakat. Keuntungan secara nyata terhadap ekonomi masyarakat dari kegiatan ekowisata mendorong masyarakat menjaga kelestarian kawasan alam. Menjaga keharmonisan dengan alam. Semua upaya pengembangan termasuk pengembangan fasilitas dan utilitas harus tetap menjaga keharmonisan dengan alam. Apabila ada upaya disharmonize dengan alam akan merusak produk wisata ekologis ini. Hindarkan sejauh mungkin penggunaan minyak, mengkonservasi flora dan fauna serta 
menjaga keaslian budaya masyarakat. Daya dukung lingkungan. Pada umumnya lingkungan alam mempunyai daya dukung yang lebih rendah dengan daya dukung kawasan buatan. Meskipun mungkin permintaan sangat banyak, tetapi daya dukunglah yang membatasi. Peluang penghasilan pada porsi yang besar terhadap negara. Apabila suatu kawasan pelestarian dikembangkan untuk ekowisata, maka devisa dan belanja wisatawan didorong sebesarbesarnya dinikmati oleh negara atau negara bagian atau pemerintah daerah setempat (Pengusahaan Ekowisata, 2000).

Penerapan sistem ekowisata di ekosistem mangrove ini merupakan suatu pendekatan dalam pemanfaatan ekosistem tersebut secara lestari. Kegiatan ekowisata adalah alternatif yang efektif untuk menanggulangi permasalahan lingkungan di ekosistem ini seperti tingkat eksploitasi yang berlebihan oleh masyarakat dengan menciptakan alternatif ekonomi bagi masyarakat (Muhaerin, 2008).

Wisata yang dilakukan dalam konteks ini memiliki bagian yang tidak terpisahkan dengan upaya-upaya konservasi, pemberdayaan ekonomi lokal dan saling menghargai perbedaan kultur atau budaya. Pergeseran konsep kepariwisataan dunia ke model ekowisata, disebabkan karena kejenuhan wisatawan untuk mengunjungi obyek wisata buatan. Sekiranya peluang ini dapat dimanfaatkan secara maksimal untuk menarik wisatawan mengunjungi obyek berbasis alam dan budaya penduduk lokal (Satria, 2009).

Melalui penyelenggaraan kegiatan ekowisata diwilayah pesisir, keberadaan hutan mangrove sebagai salah satu ekosistem pesisir yang penting, dilindungi sekaligus dikembangkan sebagai atraksi wisata dengan berbagai kegiatan yang menarik. (Mukaryanti dan Saraswati, 2005).

\section{Kesimpulan}

Melihat potensi yang besar yang dimiliki oleh ekosistem pesisir pantai labuhan haji kabupaten Lombok Timur, berpeluang besar untuk dikembangkan menjadi daerah ekowisata. Bukan hanya sekedar daerah pariwisata yang tidak disertai dengan upaya pemeliharaan yang dilakukan oleh pengelola dan masyarakat penerima manfaat jasa lingkungan yang diberikan oleh ekosistem pesisir pantai Labuhan Haji Kabupaten Lombok Timur.

\section{Daftar Pustaka}

Adrianto, L. Kusomastanto, T. 2013. Pemodelan Valuasi Keterkaitan Ekosistem Lamun di

Pulau Bintan. Bogor. Institut Pertanian Bogor

Arkhan, M., Adrianto L., dan Wardiatmo Y., 2015. Studi Keterkaitan Ekosistem Lamun dan Perikanan Skala Kecil (Studi Kasus: Desa Malang Rapat dan Beraki, Kabupaten Bintan Kepulauan Riau). J. Sosek KP (10): 137-148.

Costanza, R., dArge, R., deGroot, R., Farber, S., Gasso, M., Hannon. 1997. The Value of the World's Ecosystem Services and Natural Capital. Nature 387: 253-260.

Dahuri, R., Rais J., Ginting S.P., Sitepu, M.J. (cet. 2), 2001 : Pengelolaan Sumberdaya Wilayah Pesisir dan Lautan Secara Terpadu ; PT. Pradnya Paramita, Jakarta, Indonesia.

Darmawan, 2015. Artikel Ilmiah: Valuasi Ekonomi Layanan Ekosistem Kawasan Objek Wisata Gunung Menumbing Di Kabupaten Bangka Barat. Bandung: Universitas Padjajaran.

Gunn CA. 1994. Tourism Planning: Basics, Concepts, Cases. Third Edition. London: Taylor and Francis Ltd.Washington DC. 
Indrayanti M., Fahrudin A., dan Setyobudiandi I., 2015. Penilaian Jasa Ekosistem Mangrove di Teluk Blanakan Kabupaten Subang. Jurnal Ilmu Pertanian Indonesia (20): 91-96.

Iswadi U, 2015. Analisis potensi pengembangan Ekowisata pantai mandeh kabupaten Pesisir selatan. Sumatera Barat: Program Studi Pendidikan Geografi STKIP PGRI Sumatera Barat.

Kusmana, C. 2015. Keanekaraman hayai (Biodiversitas) sebagai Elemen Kunci Ekosistem Kota Hijau. Jurnal Biodiversitas Indonesia, Vol. 1 N0. 8. Hal. 1747-1755

Loana A., Jan H., David A., and Joern F., 2013. Synthesis Cultural Ecosystem Services: A Literature Review and Prospects for Future Researc. Ecology and Society 18 :

Muhaerin, M. 2008. Kajian Sumberdaya Ekosistem Mangrove Untuk Pengelolaan Ekowisata Di Estuari Perancak, Jembrana, Bali. Skripsi. Institut Pertanian Bogor. Bogor.

Mukaryanti dan A. Saraswati, 2005. Pengembangan ekowisata sebagai pendekatan pengelolaan sumberdaya pesisir berkelanjutan. Kasus Desa Blendung-Kabupaten Pemalang. Jurnal Teknik Lingkungan P3TL-BPPT 6 (2) : 391 - 396.

Muttaqin, T., R. H. Purwanto, dan N. R. Siti, 2011. Kajian potensi dan strategi pengembangan ekowisata di cagar alam pulau sempu Kabupaten Malang provinsi Jawa timur. GAMMA 6 (2):152-161.

Pandey A, Kotru R, and Prandhan N., 2016. A Framework for the Assessment of Cultural Ecosystem Services of Sacred Natural Sites in the Hindu Kush Himalayas Based on fieldwork in the
Kailash Sacred Landscape regions of India and Nepal. Nepal: ICCIMOD

Pengusahaan Ekowisata (2000), Chafid Fandeli., Mukhlison., Fakultas Kehutanan Univ. Gadjah Mada Yogyakarta).

Peraturan Menteri Lingkungan Hidup Nomor 17 Tahun 2009 tentang Pedoman Penentuan Daya Dukung Lingkungan Hidup, dalam Penataan Ruang Wilayah.

Saraswati, A.R. 2004. Konsep pengelolaan ekosistem pesisir (studi kasus kecamatan ulu jami kabupaten pemalang jawa tengah). Jurnal teknologi lingkungan (4):

Satria, D. 2009. Strategi pengembangan ekowisata berbasis ekonomi lokal dalam rangka program pengentasan kemiskinan di wilayah Kabupaten Malang. Journal of Indonesian Applied Economics 3(1):37-47.

Satz D., et al. 2013. The Challenges of Incorporating Cultural Ecosystem Services into Environmental Assessmen. Ambio.

Siswantoro, H. 2012. Tesis: Kajian daya Dukung Lingkunganwisata Alam Taman Wisata Alam Grojogan Sewu Kabupaten Karanganyar. Semarang: Univeristas Diponegoro.

Sabhani, A. 2010. Potensi Objek Wisata Pantai di Kabupaten Lombok Timur tahun 2010. Tesis: Universitas Sebelas Maret Surakarta.

The urbes Project.2015. Cultural Ecosystem Services - A gateway to raising awareness for the importance of nature for urban life. www.urbesproject.org

Undang-Undang Nomor 9 tahun 1990 tentang Pariwisata.

Wahyudin, Y. Kusomastanto, T. Adriyanto, L. Wardiyatno, Y. 2016. Jasa Ekosistem Lamun Bagi Kesejahteraan Manusia. 
Jurnal Omni-akuatik No. 12. Volume 3. Hal. 29-46.

Yulianda, F. 2007. Ekowisata Bahari Sebagai Alternatif Pemanfaatan Sumberdaya
Pesisir Berbasis Konservasi. Makalah Seminar Sains 21. 